\title{
JAMES IRELAND CRAIG
}

\author{
1869-1952
}

Few men have had so varied a career and so full a life as James Ireland Craig, who was killed when an Egyptian mob set fire to the Turf Club in Cairo, and attacked the Britishers within. Craig was educated at Daniel Stewart's College, where he showed a precocious skill in Mathematics and an interest in rifle shooting that was to last all his life. After leaving school as its dux in 1885, he went first to Edinburgh University and then to Emmanuel College, Cambridge, where he was a Wrangler.

A fter a short period as an assistant master in Eton and Winchester, he entered the services of the Egyptian Government. The Ministry of Education and the work of the Nile Survey occupied much of his time till his outstanding gifts as a mathematician led to his appointment as Controller of the Statistical Department.

During the latter part of the 1914-18 war he held a responsible post in the Ministry of Food in this country, and that led to his being appointed Food Controller in 1918-20 to the Upper Silesia Plebiscite Commission.

But Craig felt that it was in Egypt that his life work was to be done and he returned there as Controller General for the 1927 Census -a task not unattended with difficulty in a country with so high a proportion of illiterates. The outstanding ability which he had shown in that work and his long record of successful service led to his being appointed Financial Secretary to the Egyptian Ministry of Finance, a post he held after reaching the normal retiring age. His last appointment was that of Commissioner of Customs. He had found time to publish in 1930, in English and Arabic, a good textbook on the Elements of Analytical Geometry.

It is sad that so long and useful a life - Craig was 83 at his death - should have been ended by some of those whom he had given his life's work to serve. From all kinds of people Craig won golden opinions for what he was and for what he did. In the British Community in Cairo he was an outstanding figure. In every social group of which he was a member - and not least in the Parlour of Emmanuel - he was always welcome. The C.B.E. awarded to him in 1942 gave him - and his friends - great satisfaction.

H. J. L. Robise. 